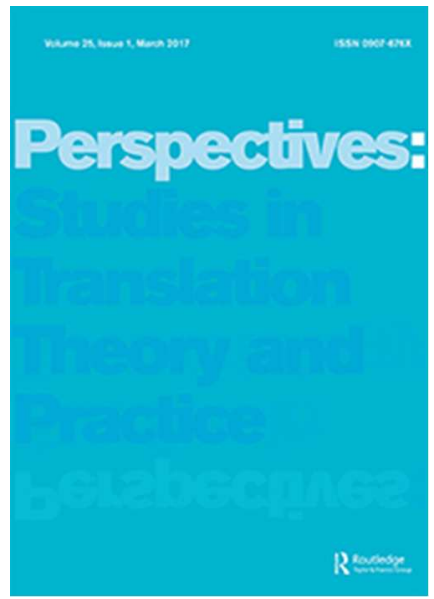

\title{
Translating reality TV into Spanish: When fast food TV challenges AVT conventions
}

\begin{tabular}{|r|l|}
\hline Journal: & Perspectives: Studies in Translation Theory and Practice \\
\hline Manuscript ID & PST-1007.R1 \\
\hline Manuscript Type: & Paper \\
\hline Keywords: & $\begin{array}{l}\text { reality TV, factual entertainment, voice-over translation, synchrony, } \\
\text { isochrony, audiovisual translation }\end{array}$ \\
& $\begin{array}{l}\text { In Spain, as in other countries, reality TV seems to be a pervasive } \\
\text { phenomenon, materialised in a myriad of domestic and foreign } \\
\text { productions. The latter require interlingual translation, which in most cases } \\
\text { takes the form of voice-over translation. Despite the prevalence of reality } \\
\text { TV and voice-over translation in Spanish television, both fields are still } \\
\text { widely underexplored. This article sets out to bridge this research gap by } \\
\text { presenting an exploratory study of the translation of reality TV in Spain. To } \\
\text { this end, it will first document the prevalence of foreign reality TV in } \\
\text { Spanish TV schedules, to then explore the similarities and differences of } \\
\text { traditional voice-over translation (i.e. used for documentary translation) } \\
\text { and voice-over translation for reality TV. The focus is on the different types } \\
\text { of synchrony observed in voice-over translation, yet the discussion } \\
\text { highlights other relevant issues (e.g. approaches to the translation of semi- } \\
\text { spontaneous speech) and illustrates how this genre is challenging } \\
\text { audiovisual translation (AVT) conventions, as well as blurring the } \\
\text { boundaries between AVT modes. }\end{array}$ \\
\hline
\end{tabular}

\section{SCHOLARONE ${ }^{\mathrm{m}}$}




\title{
Translating reality TV into Spanish: When fast food TV challenges AVT conventions
}

\author{
In Spain, as in other countries, reality TV seems to be a pervasive phenomenon, \\ materialised in a myriad of domestic and foreign productions. The latter require \\ interlingual translation, which in most cases takes the form of voice-over \\ translation. Despite the prevalence of reality TV and voice-over translation in \\ Spanish television, both fields are still widely underexplored. This article sets out \\ to bridge this research gap by presenting an exploratory study of the translation \\ of reality TV in Spain. To this end, it will first document the prevalence of \\ foreign reality TV in Spanish TV schedules, to then explore the similarities and \\ differences of traditional voice-over translation (i.e. used for documentary \\ translation) and voice-over translation for reality TV. The focus is on the \\ different types of synchrony observed in voice-over translation, yet the \\ discussion highlights other relevant issues (e.g. approaches to the translation of \\ semi-spontaneous speech) and illustrates how this genre is challenging \\ audiovisual translation (AVT) conventions, as well as blurring the boundaries \\ between AVT modes.
}

Keywords: reality TV; factual entertainment; voice-over translation; synchrony; isochrony; audiovisual translation.

\section{Introduction}

Since its emergence in the 1990s, reality TV has evolved dramatically and has made inroads into TV schedules all over the world. In Spain, it seems to be a pervasive phenomenon, materialised in a plethora of domestic and foreign productions. The latter require interlingual translation, often from English into Spanish and in the form of voice-over translation. Despite the prevalence of reality TV and voice-over translation in Spanish television, both fields are still widely underexplored in academic circles in general and in audiovisual translation (AVT) studies in particular. Voice-over translation has certainly received some scholarly attention in the past decade, but there are still many unexplored areas concerning this AVT mode, one of them being its 
adoption for the translation of non-canonical factual programmes. In the same way reality TV is watched but not valued (Hill, 2007, p. 214), voiced-over reality TV programmes have been acknowledged but not thoroughly investigated by AVT scholars. This article sets out to fill this gap, by presenting an exploratory study of the translation of reality TV in Spain, with the ultimate aim of illustrating the importance of carrying out research into 'lesser forms' of AVT.

In order to understand to what extent translated reality TV is present in Spanish TV schedules, one of the goals of this article is to analyse the programmes belonging to this genre broadcast in Spain during a sample week. The second main goal is to deepen our understanding of voice-over translation by exploring what sets apart the AVT mode used for the translation of reality TV from that used traditionally (in Spain) for the translation of non-fictional programmes, i.e. mainly documentaries. Due to space constraints, the focus will be on synchronisation as the existing literature has argued that voiced-over audiovisual texts present very specific challenges in this regard. It is also hoped that the study of synchronisation will shed light on whether, as suggested by the little research carried out so far on the translation of reality TV, this genre is transgressing AVT conventions, as well as blurring the boundaries between AVT modes.

\section{Reality TV: a very popular hybrid}

One of the challenges faced when investigating reality TV and defining this object of study is its high degree of hybridity (i.e. a great variety of programmes, formats and subgenres are often included in this genre), as well as its terminological diversity. In English, in addition to 'reality TV' we can find denominations such as 'factual television', 'factual entertainment', 'TV factual programming' or 'popular factual'. The choice of denomination is not arbitrary: as Hill (2007, p. 3) explains, factual is a value- 
laden term, and 'its association with truth, information and other conceptual values ensures it means different things to different people'. The term 'factual entertainment', for instance, highlights the tension between fiction and non-fiction that is characteristic of this subgenre. Throughout this article the term 'reality TV' will be used, as it 'has become the description used by both popular and academic critics to describe some of the most high-impact examples of the new factual television' (Dovey, 2015, p. 159), and it is also a term widely used and recognised by audiences.

Despite the great terminological diversity, most authors concur that reality TV is a macro-genre which emerged in the $1990 \mathrm{~s}$, in a landscape characterised by the proliferation of new TV channels, audience fragmentation and the search for new TV programming models (León, 2009, p. 13), and which brings together factuality and entertainment, fiction and non-fiction, real people and contrived experiences. Acknowledging that there is no one definition of the genre, Hill $(2007$, p. 5) defines reality TV as 'a catch-all category for a variety of different one-off programmes, series and formats that follow real people and celebrities and their everyday or out of the ordinary experiences'.

Several classifications (e.g. Kilborn, 2003; Hill, 2007; León, 2009) have been proposed in an attempt to categorise the great variety of reality TV products devised since they were first broadcast in the 1990s. The classification presented in Table 1, adapted from León (2009) and focused on the content of the most popular reality TV programmes, reflects the variety of formats, style and genres, while showing commonalities within each category. Nonetheless, classifications are incomplete by necessity, given the dynamic nature and hybridity that is so distinctive to this genre, as well as the constant emergence of new formats and categories. 
Table 1. Classification of reality TV based on programmes' content (adapted from León, 2009).

The popularity of reality TV seems equally undisputed. Hill (2007, p. 5), who has argued that reality TV 'makes television top heavy with reality entertainment-led programming', shows how reality TV consumption creates a contradictory viewing experience. While some viewers criticise reality programmes for being sensational and staged as well as themselves for watching what they perceive as fast food or trash television, there are also some aspects that they enjoy, such as the playful approach to ordinary people and celebrities, the spectacle of emotions or the intensity of the experiences portrayed (ibid., p. 104). Contradictions aside, the favourable share ratings ${ }^{1}$ of some of these formats seem undeniable and, in the case of Spain, this may have resulted in an increasing demand for the translation of these programmes.

\section{Reality TV in Spain}

In Spain, reality TV programmes are produced domestically and broadcast by the most popular national television channels (e.g. MasterChef in TVE, Gran Hermano (Big Brother) or Supervivientes (Survivor) in Telecinco), and some recently-created TV channels seem to rely heavily on foreign productions. The latter are not only highly exportable and cost-effective, they are also influential in as much as some of them have encouraged the creation of domestic programmes in Spanish. Gordon Ramsay's Kitchen Nightmares has its counterpart in Pesadilla en la cocina with the Spanish chef Alberto Chicote, whereas series such as Los reyes del empeño (Pawn kings) or Deja sitio para el postre (Leave room for desert) are clearly inspired by the success of series such as Hardcore Pawn or The British Bake Off respectively. Although some of these adaptations are successful (as is the case with Pesadilla en la cocina, with its $6^{\text {th }}$ season planned for 2018), many do not seem to fare as well as the originals, being either 
relegated to non-prime time slots or discontinued soon after their premiere (e.g. in the case of Los reyes del empeño).

\section{Translated reality $T V$ : what gets translated?}

The ubiquity of foreign reality TV in Spanish television, as well as its influence on domestic production models, merit further investigation. In order to have a better picture of this phenomenon and its dimensions, and to understand what gets translated in Spain as far as this genre is concerned, the schedule of Spanish TV channels was analysed during a sample week, from the $13^{\text {th }}$ to the $19^{\text {th }}$ October 2015 . The analysis was narrowed down to national television channels as the aim was to provide an overview of programmes accessible to a wider audience. A preliminary analysis revealed that, whereas domestic reality TV programmes are usually broadcast in generalist channels such as TVE or Telecinco, the following non-generic channels were the main outlets for foreign reality TV: Nova, Mega, Divinity, Energy and Discovery $\mathrm{MAX}^{2}$. As a result, a more detailed analysis was carried out for these five channels, and the main results are included in Table 2.

Table 2. Analysis of foreign reality TV programming in Spain - Summary of results A total of 49 foreign reality TV programmes (all of which were mainly translated with voice-over) were broadcast in the five channels surveyed, amounting to 18,615 minutes of translated factual entertainment. As Table 2 shows, Energy, Discovery MAX and Mega rely heavily on reality TV programmes, which make up 59\%, 54\% and $43 \%$ of their programming respectively. As regards the origin of those 49 programmes, the majority came from the US (63.3\%), but there were also exports from Canada (20.4\%), the UK (14.3\%) and even Australia (2\%). If we pay attention to the subgenre and format of the programmes, following the classification suggested in Table 1, we can see that 
coaching/lifestyle and makeover programmes were the most popular $(83.7 \%)$, followed by training/talent shows $(10.2 \%)$ and programmes based on personal interaction $(6.1 \%)$. Within the most popular category, the topics were extremely varied, with decoration/housing (22.4\%), pawn/auctions (16.3\%) and food/cooking (10.2\%) at the top of the list.

The analysis confirms the prevalence of reality TV in at least three of the five channels surveyed, as well as the variety of the audiovisual offer in this genre, especially as regards topics and formats, and the origin of the audiovisual texts, which do not only come from the US. Given the role that foreign reality TV plays in the current Spanish audiovisual market, the lack of studies in this field seems incongruous. The following section will delve into this underexplored field, paying particular attention to the use of voice-over as the main AVT mode to translate reality TV.

\section{Translating Reality TV: delving into an underexplored area}

Research on the translation of reality TV is practically non-existent. The only exception found to date is the unpublished masters' dissertation written by Permanyer (2012) analysing the Spanish context, as well as the research carried out in Italy by Sileo (2016). These publications, which will be discussed below in more detail, put a strong emphasis on the hybrid nature of both reality TV programmes and the translation mode used to render them into Spanish and Italian.

Reality TV programmes broadcast in Spain tend to be revoiced ${ }^{3}$ and are treated as non-fictional programmes as far as the AVT modes used for their translation are concerned. Following the terminology suggested in Franco et al. (2010, p. 73), these are mainly off-screen dubbing and voice-over. Off-screen dubbing is used to revoice the narration in third person often used in these programmes to introduce characters and situations, as well as to summarise and comment on what is happening on the screen. In 
this case, the original audio track with the narration is substituted with the target language version. However, when characters appear on screen (either as talking heads or having a conversation), their utterances are voiced-over, that is, the audio track containing the translation of these utterances is superimposed on the original source language track. As a result, both audio tracks can be heard, but the volume of the original track is lowered so that the translation can be fully heard and followed by the audience. Although the study of off-screen dubbing is also interesting, the focus in this article will be solely on voice-over since the proportion of narration (and therefore of off-screen dubbing) in reality TV programmes is limited if compared to talking heads and real speech ${ }^{4}$, which are the prevailing types of discourse (Permanyer, 2012, p. 29). In addition, the voice-over of these programmes seems to present distinctive characteristics worthy of investigation.

\section{Voice-over translation and reality $T V$}

Franco et al. (2010, p. 43), who have provided the most comprehensive overview of voice-over translation to date, highlight the elusiveness and complexity of this AVT mode. Their extremely detailed definition of voice-over translation shows how this mode is mainly applied to non-fictional audiovisual programmes (with the exception of some Eastern European countries where this mode is used to translate fiction), since 'its defining features contribute to the appeals of reality, truth and authenticity that factual programmes count on in order to prove that their arguments are right or believable' (ibid., p. 25). This is the case in Spain where, at least in televised productions, dubbing is still the preferred default mode for fictional products, whereas voice-over is used for non-fictional programmes. Their monograph focuses mainly on the use of voice-over in non-fictional genres, paying particular attention to documentaries and mentioning hybrid genres such as reality TV only in passing. They deem reality TV programmes 
non-fictional products by stating: '[w]e shall consider non-fictional products all sorts of documentaries (history, science, nature, archaeology, etc.), current affairs programmes, investigative journalism, docu-dramas, reality shows, talk shows, etc.' (ibid., p. 50).

Probably due to the hybrid nature of factual entertainment, not all authors concur with this view. When discussing shifts in the AVT market and pointing out that, far from being an outdated AVT mode, voice-over is gaining ground and is being used in dubbing countries to translate reality shows, Chaume (2013, p. 118) refers to these as fictional products:

$[\ldots]$ the reality series $A$ Shot at Love with Tila Tequila $[\ldots]$ was rendered in voiceover as an experiment to introduce the mode in fictional programmes (supposedly docudramas) and also as a significant way of reducing dubbing costs. Translating a fictional programme using voice-over in dubbing countries is an example of how the canon of audiovisual translation is being broken up or subverted.

These quotes raise interesting questions as regards the hybridity of reality $\mathrm{TV}$, the flexibility of voice-over translation, as well as the configuration of the ever-changing AVT landscape: Is reality TV fiction or non-fiction? Is voice-over still mainly associated with the translation of documentaries in Spain? Do voiced-over reality programmes observe the same translation conventions and norms as voiced-over nonfictional products such as documentaries? Is the AVT canon being subverted in the voice-over translation of reality TV? If so, how and why has this happened? And how do audiences perceive these shifts in the AVT landscape?

Many of these questions are still unanswered and some are rather elusive. However, the scarce research carried out on the translation of reality TV has shed some light into some of these. Aimed at determining whether generic hybridisation in television entails the hybridisation of AVT modes, Permanyer's (2012) research examines the translation of factual entertainment into Spanish. She concludes that the 
voice-over of reality TV programmes appears to honour the hybrid nature of the genre by displaying some features which are typical of dubbing:

Whereas the technique is certainly that of voice-over (that is, a revoicing method chiefly characterised by the partial availability of the original soundtrack and by the disregard for lip synchronisation), this variant seems to embrace the 'flavour' of dubbing, particularly with respect to orality and delivery (ibid., p. 55).

According to Permanyer (ibid.) this shift towards dubbing, materialised in target texts through the mirroring of some orality markers (e.g. speech disfluencies) and a clear dramatic effort in the oral delivery of the translation, seems to respond to the 'entertaining' function of the audiovisual texts being translated. Permanyer findings thus reveal that the voice-over translation of reality TV into Spanish exhibits traits that make it stand out from the voice-over translation used in documentaries, but also from dubbing. Such differences may be widely acknowledged in the industry, and in other contexts have even resulted in the coinage of new terms to refer to this AVT mode. As Sileo (2016: 408) explains, the term 'simil synch" ${ }^{5}$ is used in Italy to refer to an AVT mode in between dubbing and voice-over, used for the translation of factual genres in general and reality TV programmes in particular. She proposes the use of a more suitable and less anglicised term, 'semi-sinc', to refer to this translation practice that requires a higher degree of synchrony than traditional voice-over, yet without reaching dubbing standards (no lip synchrony is required).

Like Chaume, Sileo believes that the creation of this relatively new AVT mode responds to financial criteria, arguing that it offers an optimal compromise, both financially and from a translation point of view, as it allows audiences to enjoy a sufficiently dramatised dialogue at reduced rates and faster turnaround times if compared to dubbing (ibid., p. 410). In addition to dramatisation, both Permanyer and Sileo suggest that the voice-over translation of reality TV presents specific traits as 
regards synchronisation. To contribute to the discussion, the following section will investigate this further.

\section{Synchronisation in the translation of reality TV into Spanish}

This section examines what types of synchronies are present in the voice-over of selected reality TV programmes translated from English into Spanish. The aim of such analysis is to establish whether the different types of synchronies observed in the voiceover of documentaries and other non-fiction programmes are also used in the revoicing of reality TV in Spain. Given the difficulty of determining in an accurate manner the exact timings of the revoiced track and of quantifying examples of synchronisation, the aim of this section is not to provide quantitative data, but rather to offer an overview of the synchronies at play in the texts chosen, based on a qualitative analysis. The nature of this study is therefore exploratory, and thus findings need to be further investigated.

The qualitative analysis is based on three episodes of three different reality TV programmes, broadcast during the sample week analysed above, as shown in Table 3.

Table 3. Sample corpus: reality TV programmes analysed

Whereas the selection of episodes is by no means exhaustive or representative and was determined by the availability of the material at the time of the research, an attempt was made to choose programmes belonging to the most popular type of reality TV (coaching/ lifestyle and makeover programmes). Within this category, three series covering very different formats and topics and broadcast in different channels were chosen. In addition, the selection ensured that the revoicing had not been commissioned by the same dubbing studio.

In the following sections, each of the different types of synchrony typically observed in the voice-over translation of documentaries - namely, voice-over 
isochrony, literal synchrony, action synchrony and kinetic synchrony - will be first defined and subsequently documented looking at examples from the sample corpus.

\section{Voice-over isochrony vs. isochrony}

According to Sepielak and Matamala (2014, p. 149) voice-over isochrony 'refers to the fact that the translation should fit the time available for the voice-over, which corresponds to the length of [the] original utterance minus a few seconds at the beginning and at the end'. For many authors those few seconds and the resulting delay effect are voice-over's most characteristic feature, which results in the feeling of reality attributed to this AVT mode. There does not seem to be an agreement on the number of seconds or speech units which should be left and even on whether this is at all necessary, but 'the general practice seems to be to leave a few seconds at the beginning' (Franco et al., 2010, p. 80). However, is this also the general practice in the voice-over translation of reality TV in Spain? Both Sileo (2016, p. 407) and Permanyer (2012, p. 42) suggest that isochrony in voice-over is closer to dubbing, where the duration of the translation has to be exactly the same as that of the original and should start and end at the same time, paying attention to when the original actor's mouth opens and closes (Chaume, 2012, p. 69). In order to ascertain whether synchronisation in the sample corpus is closer to voice-over isochrony or to dubbing isochrony, attention should be paid to the beginning and end of the translation track if compared to the original one, as well as to the management of pauses in between utterances, as the latter are relevant in dubbing, but not in voice-over.

The analysis carried out reveals that the general practice of leaving a few seconds at the beginning of the utterance is disregarded in the voice-over translation of reality TV programmes. As illustrated in Table 4, the findings are diverse, not only between series but also within the same episode of a series (i.e., examples of all possible 
delivery options can be found), and it is difficult to draw clear conclusions as regards what the general practice in the translation of reality TV programmes might be. Nevertheless, the results suggest some trends, which will be discussed below.

Table 4. Voice-over isochrony in reality TV - summary of results

Within each series, one specific approach seems to be more general than others (this has been highlighted in bold in Table 4). In Pawn Stars, it is frequent to leave some time at the beginning of the utterance (often less than one second), but to finish it in synchrony with the original, whereas both in Income Property and Kitchen Nightmares, more isochronous utterances seem to be the norm. This is probably due to the format of the programmes, since Pawn Stars resembles more traditional non-fictional programmes, such as documentaries (e.g. more abundant use of talking heads, less conversation and fast-paced dialogue, more emphasis on content and not so much on dramatic events taking place throughout the episode, etc.) whereas Income Property and especially Kitchen Nightmares are closer to fictional programmes. Nevertheless, these can only be regarded as hypothesis to be tested in future studies given the qualitative nature of the analysis and the small size of the sample investigated.

Examples of all possible delivery options as regards isochrony/voice-over isochrony can be found in the series analysed, thus revealing the lack of clear guidelines as far as the implementation of this type of synchrony is concerned. As such, we find examples of the traditional use of voice-over isochrony, where some time is left at the beginning and at the end of the utterance, as shown in Example 1, where the speech units that can be heard have been underlined in the original. This is however the exception and not the general rule.

Example $1^{7}$

\begin{tabular}{llll} 
Series & Original & Translation & Back translation \\
\hline
\end{tabular}




\begin{tabular}{|c|c|c|c|}
\hline & $01: 22: 33$ & 01:22:95 & \\
\hline Pawn Stars & $\begin{array}{l}\text { Owner (Talking Head): I've } \\
\text { decided to come to the pawn } \\
\text { shop today to try to sell a } \\
\text { Philippine sword called the } \\
\text { Kris and... }\end{array}$ & $\begin{array}{l}\text { Dueño: Hoy vengo a la } \\
\text { casa de empeños para } \\
\text { vender un sable Kris de } \\
\text { las Filipinas. }\end{array}$ & $\begin{array}{l}\text { Owner: Today I've } \\
\text { come to the pawn shop } \\
\text { to sell a Kris sword } \\
\text { from the Philippines. }\end{array}$ \\
\hline Income & $03: 55: 34$ & 03:55:85 & \\
\hline & $\begin{array}{l}\text { Scott: All right, David and } \\
\text { Peter. You guys are very } \\
\text { ambitious. You bought your } \\
\text { first home. It's an income } \\
\text { property and you're hoping } \\
\text { that the two-bedroom income } \\
\text { suite on the main floor can pay } \\
\text { for the entire mortgage. }\end{array}$ & $\begin{array}{l}\text { Scott: Bien, David y } \\
\text { Peter. Sois bastante } \\
\text { ambiciosos. Habéis } \\
\text { comprado vuestra } \\
\text { primera casa / y } \\
\text { esperáis que el } \\
\text { apartamento de dos } \\
\text { dormitorios que tenéis } \\
\text { en la planta principal } \\
\text { pague toda la hipoteca. }\end{array}$ & $\begin{array}{l}\text { Scott: Okay, David and } \\
\text { Peter. You are quite } \\
\text { ambitious. You've } \\
\text { bought your first house } \\
\text { / and you hope that the } \\
\text { two-bedroom } \\
\text { apartment that you } \\
\text { have on the main floor } \\
\text { pays for the entire } \\
\text { mortgage. }\end{array}$ \\
\hline $\begin{array}{l}\text { Kitchen } \\
\text { Nightmares }\end{array}$ & $\begin{array}{l}\mathbf{0 1 : 4 3 : 8 9} \\
\text { Joe (Talking Head): I was } \\
\text { trained and worked for many } \\
\text { old-school chefs that were } \\
\text { European. }\end{array}$ & $\begin{array}{l}\text { 01:45:08 } \\
\text { Joe: Me formé y } \\
\text { trabajé para muchos } \\
\text { chefs europeos de la } \\
\text { vieja escuela. }\end{array}$ & $\begin{array}{l}\text { Joe: I trained and } \\
\text { worked for many } \\
\text { European chefs from } \\
\text { the old school. }\end{array}$ \\
\hline
\end{tabular}

In order to leave some speech units at the beginning and at the end, the translation has to be revoiced at a faster pace than the original, as in the example from Kitchen Nightmares, which takes advantage of Joe's very slow pace in the original, or has to be condensed, as in the examples from Pawn Stars and Income Property. Whereas in Pawn Stars a shorter translation is achieved by omitting some units (e.g. 'I've decided') and by finishing the incomplete utterance at the end, which is typical of spontaneous speech, in Income Property it is a result of the omission of the term 'income property', which does not have a straight forward equivalent in Spanish. Rendering this term would involve using a paraphrase and therefore a longer translation, which is unnecessary given that the meaning of the term is clear in the sentence and it is precisely what the whole series is about. These examples and their exceptionality in the sample analysed suggest that there was not a clear intention to leave those speech units heard at the beginning and especially at the end of those utterances, and that this was rather fortuitous. 
In the sample analysed, when voice-over synchrony is maintained, as Franco et al. (2010) suggested, leaving some speech units or milliseconds (often half a second) at the beginning seems to be more common than leaving them at the end. Whenever this approach is adopted, either the translation is slightly condensed to finish at the same time as the original, or it results in the whole translation being delayed until there is a significant pause or the conversation finishes. Unless substantial, the delay is unnoticeable, especially as the audience is already expecting some kind of asynchrony in the revoicing. In Example 2, extracted from Income Property, the delay in the two utterances rendered in voice-over isochrony has a knock-on effect as the conversation that ensues is fast-paced. However, time is gained through the omission of repeats (this is-this is; it's-it's), and some discourse markers (you know, well). This is typical of voice-over translation, where oral features 'are sacrificed, unless they are especially meaningful, in order to achieve voice-over isochrony and for the sake of clarity and intelligibility that is required by the genre' (Franco et al. 2010, p. 74).

\section{Example 2 - Income Property}

\begin{tabular}{|c|c|c|}
\hline Original & Translation & tion \\
\hline 01:26:13 & 01:26:74 & \\
\hline $\begin{array}{l}\text { Scott: What is happening } \\
\text { here? }\end{array}$ & $\begin{array}{l}\text { Scott: ¿Qué ha pasado } \\
\text { aquí? }\end{array}$ & Scott: What's happened here? \\
\hline $\begin{array}{l}\text { David: This is- this is one } \\
\text { of the favourites. }\end{array}$ & $\begin{array}{l}\text { David: Esto es uno de } \\
\text { nuestros favoritos. }\end{array}$ & $\begin{array}{l}\text { David: This is one of our } \\
\text { favourites. }\end{array}$ \\
\hline $\begin{array}{l}\text { Scott: That's whose } \\
\text { favourite? Not mine! }\end{array}$ & $\begin{array}{l}\text { Scott: Favorito para ti, no } \\
\text { para mí. }\end{array}$ & $\begin{array}{l}\text { Scott: Favourite for you, not for } \\
\text { me. }\end{array}$ \\
\hline David: Yeah.. & David: Ya... & David: Yes. \\
\hline 01:30:51 & 01:31:22 & \\
\hline $\begin{array}{l}\text { Scott: Where do we put the } \\
\text { upper cabinets? Well, there's } \\
\text { a window here, so let's just } \\
\text { throw them in the middle of } \\
\text { the room! }\end{array}$ & $\begin{array}{l}\text { Scott: ¿Dónde ponemos los } \\
\text { armarios superiores? } \\
\text { Bueno, aquí hay una } \\
\text { ventana, así que vamos a } \\
\text { meterlos en medio de la } \\
\text { sala. }\end{array}$ & $\begin{array}{l}\text { Scott: Where do we put the } \\
\text { upper cabinets? Well, here } \\
\text { there's a window, so let's just put } \\
\text { them in the middle of the room. }\end{array}$ \\
\hline $\begin{array}{l}\text { Scott: And there's a massive } \\
\text { bulkhead there. You've got, } \\
\text { you know, nine-foot } \\
\text { ceilings down here. Ten-foot } \\
\text { ceilings almost and two feet } \\
\text { of that is total waste. You } \\
\text { guys were living in this }\end{array}$ & $\begin{array}{l}\text { Scott: Y hay un saliente } \\
\text { enorme ahí. Son unos dos } \\
\text { metros ochenta, casi tres } \\
\text { metros. Y prácticamente } \\
\text { dos están desperdiciados. } \\
\text { ¿Habéis vivido aquí durante } \\
\text { un tiempo? }\end{array}$ & $\begin{array}{l}\text { Scott: And there's a huge } \\
\text { bulkhead there. It's } 2.80 \text { metres, } \\
\text { nearly three metres. And } \\
\text { practically two are wasted. You } \\
\text { have been living here for some } \\
\text { time? }\end{array}$ \\
\hline
\end{tabular}


space for a little bit?

Peter: Yeah!

Scott: And it's functional, right?

David: It is.

Peter: (overlaps) Well, that's the thing. It's-it's, I mean, it's hideous, but it's fine (laughs).
Peter: Sí.

Scott: Y es funcional, ¿verdad?

David: Eso es.

Peter: Esa es la cuestión. Es... quiero decir... es espantoso, pero está bien.
Peter: Yeah.

Scott: And it's functional, right?

David: That's right.

Peter: That's the question. It's, I mean, it's hideous, but it's fine.

Nevertheless, in this and in other examples we can see a clear attempt to reproduce certain features of spontaneous conversation (e.g. in 'Es... quiero decir... es espantoso'), even when their omission would result in a more synchronous delivery.

As shown in example 2, in some cases it seems that voice-over synchrony in reality TV programmes is implemented in conversational segments or blocks, delimited by pauses or silences, rather than in separate utterances. In the first block, the pause before 'Where do we put the upper cabinets?' allows to catch up time slightly, whereas in the second block this is done while Peter laughs, as laughter and other paralinguistic utterances (e.g. those consisting of primary interjections such as wow! or bam!) are not revoiced. This constitutes another interesting finding which merits further research, as a feature which brings voiced-over reality TV programmes closer to documentaries.

Before carrying out the analysis, it was expected that voice-over isochrony would be more prevalent in the translation of talking heads than in the translation of spontaneous dialogue, since the pace of this type of discourse is normally slower. In addition, the audience might associate this with documentaries and will thus expect this kind of synchrony to be maintained. However, this does not seem to be the case. In fact, some examples where the translation started slightly before and not after the original were found in the revoicing of talking heads, as shown in Example 3, from Pawn Stars. Indeed, condensing semi-spontaneous utterances (i.e. last sentence in Example 3), 
where oral markers abound, seems easier than dispensing with relevant semantic

information in Rick's first utterance.

Example 3 - Pawn Stars

Original

14:06:47

Rick (Talking Head): Michael

Jackson was a superstar of superstars.

He was known worldwide as the

King of Pop and a lot of his

memorabilia has come on the market

lately due to his death.

Owner: This is a Hawaii newspaper where they ran my photo the day he died.

Rick: Newspaper have the right to the photo or you do?

Owner: (Overlapping) No, no, I have the rights to the photos, yeah.
Translation

14:06:04

Rick: Michael Jackson era la superestrella de las superestrellas. Se le conocía en el mundo entero como el Rey del pop y muchos objetos relacionados con él se han puesto a la venta tras su muerte.

Dueño: Este es el periódico hawaiano donde pusieron mi foto el día que murió.

Rick: ¿El periódico tiene los derechos de las fotos o los tienes tú?

Dueño: Los tengo yo.
Back translation

Rick: Michael Jackson was the superstar of superstars. He was known all over the world as the King of Pop and many objects related to him have come on the market after his death.

Owner: This is the Hawaiian newspaper where they ran my photo the day he died.

Rick: The newspaper has the rights to the photos or you do?

Owner: I have them.

It was also expected to find that isochrony would be more common in the revoicing of hasty and fast-paced conversations, where it would be practically impossible to resort to any delay effect. Whereas the analysis has corroborated that fast-paced dialogue is often revoiced in synchrony with the original utterance - which as a result can hardly be heard in the background -, I would like to contend that in most cases we cannot really speak of isochrony as such because there is not an attempt to carefully respect and match the duration of the original, as is the case in lip-synch dubbing. Indeed, in many cases synchrony is maintained at the beginning of the utterance, but not at the end, which could not be regarded as isochronous delivery. Nonetheless, due to the imperceptibility of such delays, the audience may perceive these utterances as isochronous when watching voiced-over reality TV programmes, and this might indeed be the goal of producers and dubbing studios when choosing this AVT mode for the translation of this genre. In addition, for isochrony to be maintained, pauses in the original utterances would need to be respected, which does not seem to be the case, at least in two of the programmes analysed. 
Pauses and overlapping utterances

Both in Pawn Stars and in Income Property, pauses in between utterances are disregarded when revoicing the translation, or included even if they were not present in the original (see Income Property text in Example 1). The only exception is when action or kinetic synchrony need to be complied with, i.e., when the translation refers to something on screen and maintaining such pause is essential, as will be illustrated when discussing this type of synchrony below.

The treatment of pauses is different in Kitchen Nightmares where, if the character is on screen, pauses are respected and utterances are often revoiced in isochrony with the original, as normally done in dubbing, the only difference being that the original soundtrack can be heard at times in the background.

Example 4 - Kitchen Nightmares

\section{Original}

03:10:88

Tom (Talking Head): They turn brown, they start smelling. I'm like, / I would not eat that! $[\ldots]$

Kaleigh (Talking Head): He makes it very unbearable / to even be here.
Translation

03:10:88

Tom: Se ponen marrones, empiezan a oler. Yo, / yo no me lo comería.

[...]

Kaleigh: Hace que estar aquí / sea insoportable.

\section{Back translation}

Tom: They turn brown, they start smelling. I, / I would not eat that. [...] Kaleigh: He makes being here / unbearable.

We can also notice significant differences between programmes as regards the management of overlapping utterances, analysed here as it has an impact on synchrony. Investigating these is also interesting since they are often avoided in the voice-over of non-fiction programmes, again for the sake of clarity and intelligibility. In Pawn Stars overlapping or short fast-paced utterances are either not translated, especially if it does not add much from a semantic point of view (e.g. if it shows agreement from the speaker or includes interpersonal discourse markers), or delivered without overlapping in the translation (e.g. the translation is shortened, as shown in Example 3). On the contrary, in Income Property, these are reproduced in the translation. Example 5 
illustrates the different treatment of this phenomenon. In 5a overlapping or fast-paced short utterances are omitted even if the viewer can clearly see the owner on screen nodding and laughing, probably to avoid confusion and incurring a greater delay in the revoicing, as Rick speaks rather fast. In 5b overlapping utterances are rendered even if this results in an even greater delay (which the translator or voice talents do not try to remedy by condensing utterances further, even if this could be easily done) and in one case in an intelligible utterance as we hear at the same time two translated utterances and the original in the background.

\section{Example 5}

(a) Pawn Stars

\begin{tabular}{|c|c|c|}
\hline Original & Translation & Back translation \\
\hline 02:39:46 & 02:39:50 & \\
\hline $\begin{array}{l}\text { Rick: I really like it. I } \\
\text { mean, it's cool! I think it } \\
\text { would sell real quick } \\
\text { because weird thing sell. } \\
\text { Owner: (overlaps) Right } \\
\text { (laughs). }\end{array}$ & $\begin{array}{l}\text { Rick: Me gusta mucho. } \\
\text { Creo que lo vendería } \\
\text { rápido porque las cosas } \\
\text { raras se venden. }\end{array}$ & $\begin{array}{l}\text { Rick: I like it a lot. I } \\
\text { think it would sell } \\
\text { quick because weird } \\
\text { thing sell. }\end{array}$ \\
\hline $\begin{array}{l}\text { Rick: But to tell you the } \\
\text { truth I don't know enough } \\
\text { about it to make an offer. I } \\
\text { have a buddy who knows } \\
\text { everything there is to know } \\
\text { about weapons like this. } \\
\text { Owner: Right. }\end{array}$ & $\begin{array}{l}\text { Rick: Pero si le digo la } \\
\text { verdad, aún no puedo } \\
\text { hacerle una oferta. } \\
\text { Tengo un amigo que } \\
\text { sabe todo lo que hay que } \\
\text { saber sobre armas así. }\end{array}$ & $\begin{array}{l}\text { Rick: But to tell you } \\
\text { the truth I can't make } \\
\text { you an offer yet. I have } \\
\text { a friend who knows } \\
\text { everything there is to } \\
\text { know about weapons } \\
\text { like this. }\end{array}$ \\
\hline
\end{tabular}

\section{(b) Income Property}

\begin{tabular}{|c|c|c|}
\hline Original & Translation & Back translation \\
\hline 01:12:41 & 01:12:93 & \\
\hline $\begin{array}{l}\text { Scott: } \underline{\text { Let's check out this }} \\
\text { income suite. }\end{array}$ & $\begin{array}{l}\text { Scott: Veamos el } \\
\text { apartamento. }\end{array}$ & $\begin{array}{l}\text { Scott: Let's see the } \\
\text { apartment. }\end{array}$ \\
\hline $\begin{array}{l}\text { Peter: So... this is our... } \\
\text { main rental unit. One big } \\
\text { room, living room space, } \\
\text { small, condensed... }\end{array}$ & $\begin{array}{l}\text { Peter: Esta es la parte } \\
\text { principal para alquilar: } \\
\text { una gran habitación, sala } \\
\text { de estar, pequeña, } \\
\text { apretada... }\end{array}$ & $\begin{array}{l}\text { Peter: This is the main } \\
\text { part to rent out: one big } \\
\text { room, living room, } \\
\text { small, tight... }\end{array}$ \\
\hline $\begin{array}{l}\text { Scott: Did you say one big } \\
\text { room? }\end{array}$ & $\begin{array}{l}\text { Scott: ¿Has dicho una } \\
\text { gran habitación? }\end{array}$ & $\begin{array}{l}\text { Scott: Did you say one } \\
\text { big room? }\end{array}$ \\
\hline $\begin{array}{l}\text { Peter: Ah... yeah, well, } \\
\text { just for the kitchen and... } \\
\text { David: (overlaps) Well, } \\
\text { one small narrow room. }\end{array}$ & $\begin{array}{l}\text { Peter: Sí, bueno, está la } \\
\text { cocina y el comedor. } \\
\text { David: (P) Bueno... } \\
\text { (ininteligible) }\end{array}$ & $\begin{array}{l}\text { Peter: Yes, well, } \\
\text { there's the kitchen and } \\
\text { the dining room. } \\
\text { David: (overlaps) }\end{array}$ \\
\hline
\end{tabular}




$\begin{array}{lll}\text { Scott: One narrow room. } & \text { Scott: (P) Una sala } & \text { Well, (unintelligible). } \\ \text { Peter: Well, one narrow } & \text { estrecha. } & \text { Scott: (overlaps) One } \\ \text { room. } & \text { Peter: Bueno, } & \text { narrow room. } \\ & \text { una sala estrecha. } & \text { Peter: Well, one } \\ & & \text { narrow room. }\end{array}$

As for Kitchen Nightmares, overlapping utterances seem to only be maintained in the translation when it is obvious that the character on screen is speaking and omission will thus make viewers wonder if they are losing relevant information, bringing this series closer to dubbing once more.

\section{Literal synchrony}

Literal synchrony, a notion embraced by Luyken et al. (1991, p. 141), is only relevant when voice-over isochrony is kept and a few seconds are left at the beginning and/or at the end of the utterance in the revoicing. It refers to the need to provide a literal translation when the original soundtrack can be heard. As voice-over isochrony is not systematically maintained in voiced-over reality TV programmes, literal synchrony, whose pertinence has already been questioned by several authors (Franco et al., 2010, p.81; Sepielak and Matamala, 2014, p. 155) is not relevant in our case. And even if we look at those cases where traditional voice-over isochrony is maintained (see Example 1), we can see no attempt to provide a literal translation, even when the original refers to proper nouns or words which could be easily recognised by a Spanish-speaking audience (as ‘Kris' or 'European' in Example 1).

\section{Action synchrony and kinetic synchrony}

These two types of synchrony concern how the translation is synchronised with what is shown on screen. Action synchrony, a notion coined by Orero (2006) as specific to voice-over translation, refers to the need to 'offer a translation which is totally coherent with the visuals' (Sepielak and Matamala, 2014, p. 157). Kinetic synchrony, maintained 
both in dubbing and in voice-over, refers specifically to the body movements of characters on screen. Following the interpretation from Franco et al. (2010), both types of synchrony seem to be respected without issues in the sample material analysed, resulting in some cases in the mirroring of the original delivery especially as regards internal pauses, as discussed above and as shown in example 6.

Example 6-Pawn Stars

\begin{tabular}{lll} 
Original & Translation & Back translation \\
\hline 14:23:30 & $\mathbf{1 4 : 2 3 : 8 2}$ & \\
Rick: And this is all you & Rick: ¿Y esto es todo lo & Rick: And this is all \\
have, or...? & que tienes? & you have? \\
Owner: $\underline{\text { I have three }}$ & Owner: Tengo tres & Owner: I have three \\
negatives: / this photo, / & negativos: / esta foto, / & negatives: / this photo, \\
this photo, / and this photo. & esta foto y / esta foto. & / this photo and / this \\
& & photo.
\end{tabular}

In keeping with kinetic synchrony, the translation in example 6 matches the movements of the owner of the photos on screen when he points at the three photos he is trying to sell. Likewise, in keeping with action synchrony, it matches the camera movements, which show one photo at a time.

When discussing the concept of kinetic synchrony, scholars (Franco et al., 2010, p. 82; Chaume, 2012, p. 70) focus mainly on how the content of the translation matches body language. However, what if it is the acting or the revoicing of the translation that does not match body language? It could be argued that this aspect 'falls outside the range of synchronization to which the translator or dialogue writer has access' (Chaume, 2004, p. 45). Nevertheless, separating linguistic and paralinguistic features is often very difficult, especially in audiovisual texts. In addition, it is relevant to our discussion as it exposes another significant difference between dubbing and voice-over translation, in particular when we look at how the translation is delivered and how emotions are conveyed. Traditionally, in the latter, 'mimetic features' such as 'accent, age, emotion, gender, intonation, orality markers, stress' are only reproduced 'to a 
certain extent' (Franco et al., 2010, p. 44). At least in Spanish voiced-over

documentaries, emotion is not conveyed, as such information can be gathered from the original soundtrack and priority is given to what has been said. However, how is this issue approached in voiced-over reality TV programmes given that a) the original soundtrack is usually not audible, and that b) due to the hybrid nature of these programmes, emotional and dramatic scenes are not only frequent but often responsible for 'entertaining' the audience?

We can see that the treatment of this issue differs in the series analysed, with emotions being reproduced as one would expect from a dubbed text in the revoicing of Kitchen Nightmares, but not in Pawn Stars and in Income Property. The latter approach can result in inconsistencies. For instance, in Example 7, from Income Property, the voice of the dubbing actor does not match the enthusiastic body movements of Scott on screen when he utters the last sentence.

\section{Example 7 - Income Property}

\begin{tabular}{|c|c|c|}
\hline Original & Translation & Back translation \\
\hline 05:24:55 & 05:24:60 & 8 \\
\hline Scott: Sounds exciting? & Scott: ¿Suena bien? & Scott: Sounds good? \\
\hline David: Sounds exciting. & David: Suena bien. & David: Sounds good. \\
\hline Scott: Not exciting & Scott: No lo suficiente. & Scott: Not enough. \\
\hline enough! He's like, you & Está pensando: no me ha & He's thinking: he didn't \\
\hline didn't get me to the two & dado los dos mil dólares & give me the two \\
\hline $\begin{array}{l}\text { thousand I asked for! } \\
\text { (laughs) }\end{array}$ & que & $\begin{array}{l}\text { thousand dollars I } \\
\text { asked for. }\end{array}$ \\
\hline
\end{tabular}

In this case, if we allow for a broader understanding of kinetic synchrony, it could be argued that it is only partially maintained. Likewise, it could be argued that viewers can see Scott's body movements on screen and reproducing emotion is not necessary, but this is also the case in Kitchen Nightmares, where characters body language clearly show they are shouting and arguing, and still emotion is reproduced by voice actors. In any case, these examples illustrate yet another inconsistency in how key issues are managed in the voice-over translation of reality TV into Spanish. 


\section{Conclusions and further remarks}

Whether we like it or not, reality TV is one of the staples of current TV schedules all over the world, and Spain is no exception. The exploratory study conducted here has shown the important role voiced-over reality TV programmes play on Spanish TV, not only in quantitative terms, but also as regards their influence on domestic productions. It has also revealed the chameleonic nature of voice-over translation when it comes to the translation of reality TV, thus showing how 'fast food TV' has pushed the boundaries between AVT modes and transgressed AVT conventions. At times, voiced-over reality TV takes the form of traditional voice-over (neutralisation of orality markers and other features that might compromise intelligibility, omission of paralinguistic utterances, instances of voice-over isochrony, etc.), but it also mutates into dubbing on occasion (revoicing of emotion in some programmes, mirroring of features typical of real speech, isochronous renderings, etc.).

The exploratory study undertaken has shown that the types of synchrony observed in the voice-over of reality TV in Spain present differences if compared to those observed in documentaries, especially as regards voice-over isochrony and literal synchrony. The results are thus in line with the reflections and findings of existing research (Permanyer, 2012; Sileo, 2016), but it is here argued that we cannot speak of isochrony in dubbing terms, since the original and the translation may start at the same time but do not often finish in synchrony, internal pauses are not always maintained, and the duration of both tracks is rarely exactly the same. We are thus dealing with a more flexible type of isochrony, where the duration of the translation has to correspond approximately with that of the original, providing voice talents and sound technicians enough leeway to deliver it in synchrony with the original, or to resort to a slight 
asynchrony. This flexible approach allows for an intermittent and discretionary use (e.g. in conversational blocks) of voice-over isochrony as defined in the existing literature.

A question that arises is whether it is necessary to coin a new term to designate this translation practice or this flexible type of isochrony (e.g. flexi-synchrony), especially within the Spanish context. Coming up with a new term that will not be used consistently seems futile, and it is probably wiser and more productive to revisit existing terms (e.g. half-dubbing or semidoblaje ${ }^{8}$ ) or to expand current definitions of voice-over translation. These should acknowledge the irrelevance of literal synchrony and no longer consider the delay effect as voice-over's most characteristic feature. Likewise, the omission or neutralisation of specific features of real speech (e.g. intonation, orality markers, overlapping utterances) is no longer justified since voiceover isochrony allows for flexibility, and clarity and intelligibility are not the main priority in some genres. As such, the emphasis of voice-over translation can easily shift from content and intelligibility to form and dramatisation. Regarding the latter, the revoicing of emotions, discussed when analysing kinetic synchrony, is inconsistent in the sample analysed, with some approaches giving priority to the entertaining purpose of these programmes (e.g. Kitchen Nightmares), but only partially (i.e. laughter and other paralinguistic utterances are never revoiced).

In this sense, this study has also revealed a lack of a clear pattern or guidelines. This is not surprising given the relative youth of this translation practice, as well as its experimental nature, whereby an approach typically used for factual programmes is being adopted for the translation of formats which may be closer to fictional ones. Whereas some trends can be identified (e.g. in general terms, the revoicing of Kitchen Nightmares is closer to dubbing than to traditional voice-over, Pawn Stars is closer to traditional voice-over and Income Property sits somewhere in between), the results 
presented here require further investigation. Involving the translation industry is essential to understand inconsistencies and undertaking more specific studies should provide more pertinent results. Nevertheless, it is hoped that this paper has met its aim of showing the relevance of studying lesser forms of AVT, unveiling at the same time topics which merit further investigation, such as the translation and revoicing of paralanguage and orality markers in reality TV.

As a final remark, in the case of reality TV, we cannot argue that voice-over has been chosen to foster the illusion of authenticity and truth in the audience, since: a) this is not the sole aim of reality TV, which also places a strong focus on entertainment, for which voice-over is clearly not the most appropriate option in some audiovisual contexts (e.g. in Spain or Italy); b) the original soundtrack is quite often inaudible (as a result of the overlapping, not because it is muted or replaced by the translation) and therefore audiences are not exposed to the original as they are in documentaries, for example. In this regard, back in 2001, Mayoral already questioned the suitability of voice-over for fostering authenticity in the translation of documentaries into Spanish, arguing that the original audio was mostly incomprehensible for viewers. In addition, he urged to explore other AVT modes to find more suitable ways to translate documentaries. It seems this is what the industry has done in the case of reality TV, where the experimenting in pursuit of the most effective solution (arguably in terms of cost) is still ongoing and has resulted in the transgression of existing AVT conventions and modes. This article has focused on how this reality takes shape in Spanish television, but the situation is likely to be similar in comparable scenarios, which would also benefit from further investigation. 


\section{Endnotes}

1. In Spain, domestic reality TV programmes such as Gran Hermano (Big Brother) and training or talent shows such as La Voz (The Voice) or MasterChef and its versions (MasterChef Junior and MasterChef Celebrity) often feature in the rankings of the 50 most watched TV programmes (SGAE, 2016; 2017). Regarding the latter, for instance, since its first season in 2013 the number of viewers watching the finals of the Spanish version of MasterChef has ranged from 3.7 to 5.5 million, achieving a 25-33\% share rate (Migelez, 2016). Share ratings of Gran Hermano were impressive during the first two seasons (over 9 million viewers and $60-70 \%$ share rate for its finals) (Terán, 2012) and although they have decreased due many factors, including audience fragmentation, it is still a very popular show, with Gran Hermano VIP (Celebrity Big Brother) achieving a 29.8\% share rate in 2015 (SGAE, 2016: 64).

2. The preliminary analysis considered all those Spanish channels accessible to a wider audience (i.e. free and widely available) which were broadcasting at the time the analysis was undertaken. These comprised generic channels (TVE 1, the public Spanish TV station belonging to the state broadcaster Radio Televisión Española; Antena 3 and La Sexta, private channels belonging to Atresmedia; and Telecinco and Cuatro, private channels property of Mediaset), as well as non-generic channels. Given that non-generic channels abound, especially since the advent of Digital Terrestrial Television in Spain as a free service, the selection was narrowed down to those channels focusing on entertainment. These included Neox, Nova and Mega from Atresmedia, Divinity, FDF and Energy from Mediaset, Paramount Channel from Net TV, and Discovery MAX from Veo TV (SGAE, 2016). As foreign reality TV was hardly included (e.g. La Sexta, Cuatro, Neox) or completely absent (e.g. TVE 1, Antena 3, Telecinco, FDF and Paramount Channel) in some of these channels, it was decided to focus on those featuring a substantial amount of these texts: Nova, Mega, Divinity, Energy and Discovery MAX.

3. Although subtitles are now available for most TV programmes broadcast in Spain, reality TV programmes are available revoiced by default.

4. Following Matamala (2009), Permanyer (2012) refers to instances of unscripted conversation as 'real speech'. However, I would like to contend here that this type of discourse is at best semi-spontaneous due to the contrived nature of reality TV programmes and the careful planning they go through, which also affects their discourse.

5. According to Italian translators and scholars, this term stands for 'similar to lip synchrony', but its origin has so far not been clearly pinpointed.

6. Only the first 20 minutes of this episode have been analysed, given this is the approximate duration of the episodes from the other two series. 
7. In line with existing conventions in Spain (Chaume, 2012), the following dubbing symbols have been used in the examples: / to represent short pauses and (P) for instances of overlapping utterances. Approximate time codes have also been included in the following format: minutes:seconds:milliseconds.

8. The terms half-dubbing and partial dubbing, and relevant equivalents in other languages such as semidoblaje (Bartoll, 2016) or demi-doublage (Gambier, 2004), have been used either as synonyms of voice-over, or to denote its variations and experimentations with this AVT mode (Hendrickx, 1984; Chaume, 2013). The versatility of these terms is in line with the approach taken by Hendrickx (1984) when coining the term 'partial dubbing' and illustrating its potential as a prospective alternative to dubbing and subtitling. Yet, this has resulted in terminological confusion and nowadays these terms need to be carefully defined as they can lead to different interpretations.

\section{References}

Bartoll, E. (2015). Introducción a la traducción audiovisual. Barcelona: UOC.

Chaume, F. (2004). Synchronization in dubbing: a translational approach. In P. Orero (Ed.), Topics in Audiovisual Translation (pp. 35-52). Amsterdam/Philadelphia: John Benjamins.

Chaume, F. (2012). Audiovisual Translation: Dubbing. Manchester: St. Jerome.

Chaume, F. (2013). The turn of audiovisual translation. New audiences and new technologies. Translation Spaces, 2, 105-123.

Dovey, J. (2015). Reality TV - Introduction. In G. Creeber (Ed.), The Television Genre Book (pp. 35-52). London: Palgrave.

Franco, E., Orero, P. \& Matamala, A. (2010). Voice-Over Translation: An Overview. Bern/Oxford: Peter Lang.

Gambier, Y. (2004). La traduction audiovisuelle : un genre en expansion. Meta, 49(1), $1-11$.

Hendrickx, P. (1984). Partial dubbing. Meta, 29(2), 217-218.

Hill, A. (2007). Restyling Factual TV: Audiences and News, Documentary and Reality Genres. Oxon: Routledge.

Kilborn, R. (2003). Staging the Real: Factual TV Programming in the Age of Big Brother. Manchester: Manchester University Press.

León, B. (2009). Introducción. In B. León (Ed.), Telerrealidad: El mundo tras el cristal (pp. 13-23). Seville: Comunicación Social. 
Luyken, G. M., Herbst, T., Langham-Brown, J., Reid, H. \& Spinhof, H. (1991). Overcoming Linguistic Barriers in Television. Dubbing and Subtitling for the European Audience. Manchester: EIM.

Matamala, A. (2009). Translating documentaries: from Neanderthals to the Supernanny. Perspectives: Studies in Translatology, 17(2), 93-107.

Mayoral, R. (2001). El espectador y la traducción audiovisual. In F. Chaume \& R. Agost (Eds.), La traducción en los medios audiovisuales (pp. 33-48). Castellón: Universitat Jaume I.

Migelez, X. (2016, June 30). La final de 'MasterChef 4' arrolla con récord de edición $(28,4 \%)$ y su segunda mejor marca histórica. FormulaTV. Retrieved from http://www.formulatv.com/noticias/57417/audiencias-29-junio-finalmasterchef4-marca-maximo/

Orero, P. (2006). Synchronization in voice-over. In J. M. Bravo Gonzalo (Ed.), Aspects of Translation (pp. 255-264). Valladolid: Universidad de Valladolid.

Permanyer, E. (2012). A hybrid television genre, a hybrid translation mode: Voice-over translation of factual entertainment (Unpublished master's thesis). Roehampton University, London.

Sepielak, K. \& Matamala, A. (2014). Synchrony in the voice-over of Polish fiction genres. Babel, 60(2), 145-163.

SGAE (2016). Anuario SGAE de las Artes Escénicas, Musicales y Audiovisuales 2016. Madrid: Fundación SGAE. Retrieved from http://www.anuariossgae.com/anuario2016/home.html

SGAE (2017). Anuario SGAE de las Artes Escénicas, Musicales y Audiovisuales 2017. Madrid: Fundación SGAE. Retrieved from http://www.anuariossgae.com/anuario2017/home.html

Sileo, A. (2016). Processi traduttivi ibridi per format TV ibridi: il simil sync o semi-sinc tra voice-over e doppiaggio. In Proceedings of the V Congreso SELM 2015 (pp. 403-411). Seville: Bienza.

Terán, B. (2012, May 29). El histórico de audiencias de las finales de 'Gran Hermano'. Lainformacion.com. Retrieved from http://blogs.lainformacion.com/telediaria/2012/05/29/el-historico-de-audienciade-las-finales-de-gran-hermano/ 
Table 1. Classification of reality TV based on programmes' content (adapted from

León, 2009).

\begin{tabular}{|l|l|l|}
\hline $\begin{array}{l}\text { Type of reality TV } \\
\text { programme }\end{array}$ & Description & Examples \\
\hline $\begin{array}{l}\text { Crime and emergency } \\
\text { services programmes }\end{array}$ & $\begin{array}{l}\text { Focused on the life of members of the public } \\
\text { in critical situations. }\end{array}$ & $\begin{array}{l}\text { Crimewatch (BBC), COPS } \\
\text { (Fox) }\end{array}$ \\
\hline $\begin{array}{l}\text { Charity programmes or } \\
\text { do good programmes }\end{array}$ & $\begin{array}{l}\text { Social assistance is offered to members of } \\
\text { the public in need. }\end{array}$ & $\begin{array}{l}\text { Queen for a day (NBC), } \\
\text { Miracle workers (ABC) }\end{array}$ \\
\hline $\begin{array}{l}\text { Coaching/ Lifestyle and } \\
\text { makeover programmes }\end{array}$ & $\begin{array}{l}\text { Assistance is offered to members of the } \\
\text { public who are having some kind of } \\
\text { difficulty in life (e.g. raising their children, } \\
\text { managing their businesses or their homes, } \\
\text { dealing with their finances, health and } \\
\text { hygiene, etc.). } \\
\text { They show aspects of a specific lifestyle. }\end{array}$ & $\begin{array}{l}\text { Supernanny (Channel 4), } \\
\text { (Channel 4), Esta casa era } \\
\text { una ruina (Antena 3) }\end{array}$ \\
\hline $\begin{array}{l}\text { Programmes based on } \\
\text { personal interaction }\end{array}$ & $\begin{array}{l}\text { Members of the public or celebrities are } \\
\text { arranged in groups and have to interact in } \\
\text { different situations and environments (often } \\
\text { in game show format). }\end{array}$ & $\begin{array}{l}\text { Big Brother (Endemol), } \\
\text { Survivor (CBS) }\end{array}$ \\
\hline $\begin{array}{l}\text { Training or talent shows } \\
\text { (artistic/professional) }\end{array}$ & $\begin{array}{l}\text { Members of the public or celebrities audition } \\
\text { for and perform music or other } \\
\text { artistic/professional endeavours (cooking, } \\
\text { singing, modelling, dancing, etc.) and } \\
\text { receive some kind of training while the } \\
\text { programme lasts (often in game show } \\
\text { format). }\end{array}$ & $\begin{array}{l}\text { Operación triunfo (TVE), } \\
\text { The X Factor (ITV), The } \\
\text { Great British Bake Off } \\
\text { (BBC) }\end{array}$ \\
\hline
\end{tabular}


Table 2. Analysis of foreign reality TV programming in Spain - Summary of results

\begin{tabular}{|l|r|r|r|}
\hline \multirow{2}{*}{ Channel } & \multicolumn{4}{|c|}{ Foreign reality TV programmes - 13-19 October 2015 } \\
\cline { 2 - 4 } & \multicolumn{2}{|c|}{ Minutes } & \multicolumn{2}{c|}{$\begin{array}{c}\text { Number of } \\
\text { programmes }\end{array}$} & $\begin{array}{c}\text { \% minutes within each } \\
\text { channel }\end{array}$ \\
\hline Energy & 5,900 & 11 & $59 \%$ \\
\hline $\begin{array}{l}\text { Discovery } \\
\text { MAX }\end{array}$ & 5,490 & 16 & $54 \%$ \\
\hline Mega & 4,350 & 10 & $43 \%$ \\
\hline Divinity & 2,130 & 8 & $21 \%$ \\
\hline Nova & 745 & 4 & $7 \%$ \\
\hline Total & 18,615 & 49 & \\
\hline
\end{tabular}


Table 3. Sample corpus: reality TV programmes analysed

\begin{tabular}{|l|l|l|l|l|l|l|}
\hline $\begin{array}{l}\text { Original } \\
\text { programme } \\
\text { title }\end{array}$ & $\begin{array}{l}\text { Translated } \\
\text { programme } \\
\text { title }\end{array}$ & Brief description & $\begin{array}{l}\text { Season / } \\
\text { Episode }\end{array}$ & Duration & $\begin{array}{l}\text { TV } \\
\text { Channel }\end{array}$ & $\begin{array}{l}\text { Dubbing } \\
\text { Studio }\end{array}$ \\
\hline $\begin{array}{l}\text { Income } \\
\text { Property }\end{array}$ & $\begin{array}{l}\text { Tu casa lo } \\
\text { vale }\end{array}$ & $\begin{array}{l}\text { Canadian home- } \\
\text { improvement } \\
\text { program, where } \\
\text { homeowners are } \\
\text { guided through the } \\
\text { renovation of their } \\
\text { income property. }\end{array}$ & $5 / 12$ & 20 min & Divinity & $\begin{array}{l}\text { Enboca } \\
\text { Audiovisual }\end{array}$ \\
\hline $\begin{array}{l}\text { Kitchen } \\
\text { Nightmares }\end{array}$ & $\begin{array}{l}\text { Pesadilla en } \\
\text { la cocina }\end{array}$ & $\begin{array}{l}\text { in which chef } \\
\text { Gordon Ramsay } \\
\text { visits failing } \\
\text { restaurants in an } \\
\text { attempt to revive the } \\
\text { business. }\end{array}$ & $6 / 10$ & 40 min & Nova & Best-Digital \\
\hline Pawn Stars & $\begin{array}{l}\text { US reality TV series } \\
\text { which shows the } \\
\text { activities at the } \\
\text { Gold \& Silver Pawn } \\
\text { Shop, where } \\
\text { members of the } \\
\text { public try to sell or } \\
\text { pawn their } \\
\text { belongings (mostly } \\
\text { antiques bought at } \\
\text { garage and yard } \\
\text { sales). }\end{array}$ & $2 / 27$ & 20 min & Mega & Unknown \\
\hline
\end{tabular}


Table 4. Voice-over isochrony in reality TV - summary of results

\begin{tabular}{|c|c|c|c|}
\hline \multirow{2}{*}{ Reality TV programme } & \multicolumn{2}{|c|}{ Voice-over isochrony } & $\begin{array}{c}\text { Pauses in between } \\
\text { utterances }\end{array}$ \\
\hline & Beginning of utterance & End of utterance & \multirow{4}{*}{$\begin{array}{c}\text { Not common, short and } \\
\text { quick utterances } \\
\text { generally }\end{array}$} \\
\hline \multirow{3}{*}{ Income Property } & $\begin{array}{l}\checkmark \text { The translated track } \\
\text { starts before the } \\
\text { original }\end{array}$ & $\begin{array}{l}\checkmark \text { The translated track } \\
\text { finishes before the } \\
\text { original }\end{array}$ & \\
\hline & $\begin{array}{l}\checkmark \text { The translated } \\
\text { track starts at the } \\
\text { same time as the } \\
\text { original }\end{array}$ & $\begin{array}{l}\checkmark \text { The translated } \\
\text { track finishes at } \\
\text { the same time as } \\
\text { the original }\end{array}$ & \\
\hline & $\begin{array}{l}\checkmark \text { The translated track } \\
\text { starts after the } \\
\text { original }\end{array}$ & $\begin{array}{l}\checkmark \text { The translated track } \\
\text { finishes after the } \\
\text { original }\end{array}$ & \\
\hline \multirow{3}{*}{ Kitchen Nightmares USA } & $\begin{array}{l}\checkmark \text { The translated track } \\
\text { starts before the } \\
\text { original }\end{array}$ & $\begin{array}{l}\checkmark \text { The translated track } \\
\text { finishes before the } \\
\text { original }\end{array}$ & \multirow{3}{*}{$\begin{array}{l}\text { Kept in most cases, } \\
\text { especially when the } \\
\text { character is clearly on } \\
\text { screen }\end{array}$} \\
\hline & $\begin{array}{l}\checkmark \text { The translated } \\
\text { track starts at the } \\
\text { same time as the } \\
\text { original }\end{array}$ & $\begin{array}{l}\checkmark \text { The translated } \\
\text { track finishes at } \\
\text { the same time as } \\
\text { the original }\end{array}$ & \\
\hline & $\begin{array}{l}\checkmark \text { The translated track } \\
\text { starts after the } \\
\text { original }\end{array}$ & $\begin{array}{l}\checkmark \text { The translated track } \\
\text { finishes after the } \\
\text { original }\end{array}$ & \\
\hline \multirow{3}{*}{ Pawn Stars } & $\begin{array}{l}\checkmark \text { The translated track } \\
\text { starts before the } \\
\text { original }\end{array}$ & $\begin{array}{l}\checkmark \text { The translated track } \\
\text { finishes before the } \\
\text { original }\end{array}$ & \multirow{3}{*}{$\begin{array}{l}\text { Only kept when action } \\
\text { or kinetic synchrony } \\
\text { need to be observed }\end{array}$} \\
\hline & $\begin{array}{l}\checkmark \text { The translated track } \\
\text { starts at the same } \\
\text { time as the original }\end{array}$ & $\begin{array}{l}\checkmark \text { The translated } \\
\text { track finishes at } \\
\text { the same time as } \\
\text { the original }\end{array}$ & \\
\hline & $\begin{array}{l}\checkmark \text { The translated } \\
\text { track starts after } \\
\text { the original }\end{array}$ & $\begin{array}{l}\checkmark \text { The translated track } \\
\text { finishes after the } \\
\text { original }\end{array}$ & \\
\hline
\end{tabular}

